\title{
Performance and Emission Characteristics of Cotton Seed and Hexanol Oil Biodiesel with CeO2 Additives on Single Cylinder Diesel Engine
}

\section{Anilkumar ${ }^{1}$, Dr. K. Prahladarao ${ }^{2}$}

1PG Research Scholar, Advanced Internal Combustion Engines, Department of Mechanical Engineering , Jawaharlal Nehru Technological University Anantapur College of engineering (Autonomous), Anantapuramu, Andhra Pradesh, India

${ }^{2}$ Professor, Department of Mechanical Engineering, Jawaharlal Nehru Technological University Anantapur College of engineering (Autonomous), Anantapuramu, Andhra Pradesh, India

\begin{abstract}
Energy utilization from renewable sources plays a vital role to meet the demands of theclean environment. Commercialization of biodiesel is comparatively less than the otheralternative sources due to its suitability and yield. In this paper, it is focused on performance and emission characteristics of cotton seed and hexanol oil biodiesel and in blended withcerium oxide as an additive. The blending proportion was made as B10, B15, B20, and100\% Diesel. The testing was performed in Single cylinder four stroke diesel engine. The Performance characteristics were obtained in between the brake power withspecific fuel consumption and emission characteristics such as HC CO and NOxand other gases. It was observed that the combination of B15 proportion with $\mathrm{CeO} 2$ blendproduces effect results with other blends in specific fuel consumption and reduced emissionbehavior.
\end{abstract}

Keywords : Biodiesel, Blend, Cerium oxide, Performance, Emission.

\section{INTRODUCTION}

Biodiesel is a prominent fuel replacement for the fossil fuel to meet energy demands andglobal warming issues. Among various other alternative sources of energy, biodiesel helps inobtaining immediate generation and harmless to the environment Abbas Alli et alwere undergone experiment on various biodiesel blends with $\mathrm{CeO} 2$ as the additive. Theyobservedthat the $\mathrm{CeO} 2$ helps in burning the Carbon particles deposited over the walls of the cylinders Chen $\mathrm{He}$ et al were tested using cotton seed oil with the diesel as a blend. It was observed theincrease in cetane number due to the addition of the cotton seed oil. Also, it helps in improving theefficiency of the engine Duple Sinha et al was conducted an experiment on waste seed oil as a blend with the diesel. They suggested that B10 and B20 blends show the increase inthermal efficiency and low specific fuel consumption $\mathrm{CeO} 2$ act as Oxygen donating catalyst andhelps in improving the combustion and increase in thermal efficiency of the engine . The CeO2blends will helps in obtaining lower hydrocarbons and carbon monoxide emissions. Hexanol oiland cotton seed oil posses 30 to $40 \%$ of oil content and can be used as a strong alternate for other biofuels .Md. Nurun Nabi et al were conducted an experiment on cottonseed oilbiodiesel, they observed almost $77 \%$ of biodiesel were extracted from the cotton seeds and remainingportion of methanol and other allied substances.Sandeep Singh et al wereconducted experiment of cottonseed 
biodiesel, they suggested that B10, B20 and B30 blends ofbiodiesels were a strong substitute of the mineral oil diesel and helps in obtaining the samecharacteristics of the diesel . V. Sajith et al (2015) were conducted experiment on biodieselblends with $\mathrm{CeO} 2$ as an additive in range of (20-80ppm). This addition of $\mathrm{CeO} 2$ helps inreducing $\mathrm{NOx}$ and other Emissions . Addition of $\mathrm{CeO} 2$ also having greater impact of enginecombustion, emission and performance characteristics []. Among the other additives withbiodiesel blends $\mathrm{CeO} 2$ has acted as a prominent catalyst and allows proper mixture with thebiodiesel to enhance the combustion properties

\section{METHODS AND MATERIAL}

\section{Cotton seed oil and hexanol biofuels :-}

The Cotton seed oil and hexonal biofuels was taken for the testing purpose. Theproperties of this biodiesel are shown in Table 1. The hexonal oil exhibit greater density of $880 \mathrm{Kg} / \mathrm{m} 3$, when compared to cotton seed oil of $610 \mathrm{Kg} / \mathrm{m} 3$. Also, hexonal oil has thecetane number of 51 than 48 for the cotton seed, which proves lower Nox emission thanthe cotton seed oil.

\begin{tabular}{|l|c|c|c|c|c|}
\hline $\begin{array}{l}\text { Prop } \\
\text { ertie } \\
\text { s }\end{array}$ & $\begin{array}{c}\text { Densit } \\
\text { (Kg/m3 } \\
\text { (K) }\end{array}$ & $\begin{array}{c}\text { Visco } \\
\text { sity(c } \\
\text { St })\end{array}$ & $\begin{array}{c}\text { Flashp } \\
\text { oint } \\
(0 \mathrm{C})\end{array}$ & $\begin{array}{c}\text { Ceta } \\
\text { ne } \\
\text { No }\end{array}$ & $\begin{array}{c}\text { Calorific } \\
\text { Value(KJ/ } \\
\mathrm{Kg})\end{array}$ \\
\hline $\begin{array}{l}\text { Cotton } \\
\text { seed }\end{array}$ & 610 & 5.96 & 175 & 48 & 49600 \\
\hline Hexona & 880 & 3.5 & 178 & 51 & 37000 \\
\hline
\end{tabular}

Table 1. Properties of Neem and Cotton seed oil

\section{Cerium oxide additive:-}

The cerium oxide particles of fine grain size have been added as an additive ofsuitable proportion with the biodiesel blends. This addition helps in enhancement ofvarious performance characteristics of the samples and the properties of the cerium oxide were listed in Table 2.

\begin{tabular}{|c|c|}
\hline Parameters & Values \\
\hline Molecular formula & $\mathrm{CeO} 2$ \\
\hline Molar mass & $172.115 \mathrm{~g} / \mathrm{mol}$ \\
\hline Appearance & white or pale \\
& yellow solid \\
\hline Density & $7.215 \mathrm{~g} / \mathrm{cm} 3$ \\
\hline Melting point & $2,400{ }^{\circ} \mathrm{C}\left(4,350^{\circ} \mathrm{F} ;\right.$ \\
& $2,670 \mathrm{~K})$ \\
\hline Boiling point & $3,500{ }^{\circ} \mathrm{C}\left(6,330^{\circ} \mathrm{F} ;\right.$ \\
& $3,770 \mathrm{~K})$ \\
\hline Solubility in water & Insoluble \\
\hline Crystal structure & cubic (fluorite) \\
\hline
\end{tabular}

Table 2. Properties of Cerium Oxide Additive

\section{Blending :-}

The blending of Hexonal oil and Cotton seed oil was taken in the ratio of B10, B20, B30 andin addition to the regular Diesel. The blending composition of the Samples was listed inTable 3.

\begin{tabular}{|l|c|l|}
\hline Sl No & Blend & Composition \\
\hline 1 & Blend10 & $\begin{array}{l}\text { HX-5\% + CO-5\% + } \\
90 \% \text { Diesel }\end{array}$ \\
\hline 2 & Blend 15 & $\begin{array}{l}\text { HX-7.5\% + CO- } \\
7.5 \%+85 \% \text { Diesel }\end{array}$ \\
\hline 3 & Blend 20 & $\begin{array}{l}\text { HX-10\% + CO-10\% } \\
+80 \% \text { Diesel }\end{array}$ \\
\hline 4 & Diesel & $100 \%$ Diesel \\
\hline 5 & Blend 15+ Ce0 2 & $\begin{array}{l}\text { HX-7.5\% + CO- } \\
7.5 \%+85 \% \text { Diesel }\end{array}$ \\
\hline
\end{tabular}




\begin{tabular}{|l|l|l|}
\hline & & $+20(\mathrm{ppm})$ \\
\hline 5 & Blend 15+ $\mathrm{Ce}_{2}$ & $\mathrm{HX}-7.5 \%+\mathrm{CO}-$ \\
& & $7.5 \%+85 \%$ Diesel \\
& & $+40(\mathrm{ppm})$ \\
\hline 5 & Blend $15+\mathrm{Ce}_{2}$ & $\mathrm{HX}-7.5 \%+\mathrm{CO}-$ \\
& & $7.5 \%+85 \%$ Diesel \\
& & $+60(\mathrm{ppm})$ \\
\hline
\end{tabular}

Table 3. Biodiesel blending composite

\section{ENGINE SETUP AND PROCEDURE}

For experimental testing, Kirloskar single cylinder water cooled variable diesel compression engine integrated with EGR is used. For loads on the engine, the Eddy current dynamometer is used. To apply loads to the engine, the Eddy current dynamometer is connected to the flywheel. To inject the fuel, an injection pressure of 200 bar is maintained. The pressure of the cylinder is evaluated by the piezosensor installed on the head of the engine cylinder and the angle of the crank encoded on the fly wheel. The normal engine is supplied with 0 to25oBTDC injection point variation. The $\mathrm{HC}, \mathrm{CO}, \mathrm{CO} 2, \mathrm{UBHC}$ and NOX emissions are evaluated using the fire gas analyzer AVL-DIGAS 444. AVL smoke meter measures the opacity of the smoke.

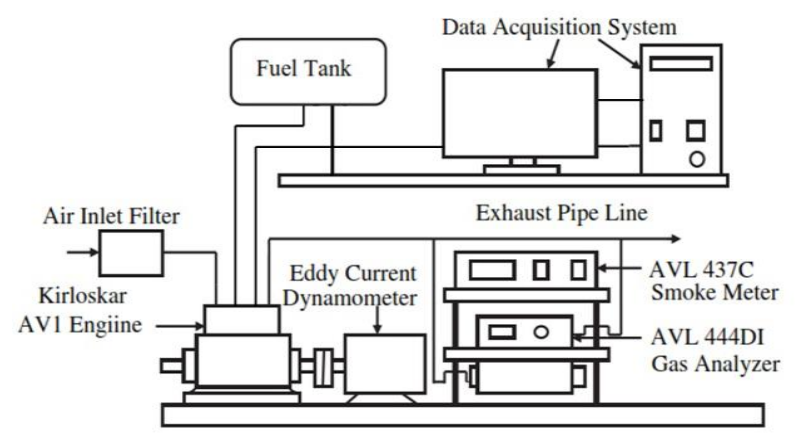

Fig.1. Schematic diagram of experimental set up
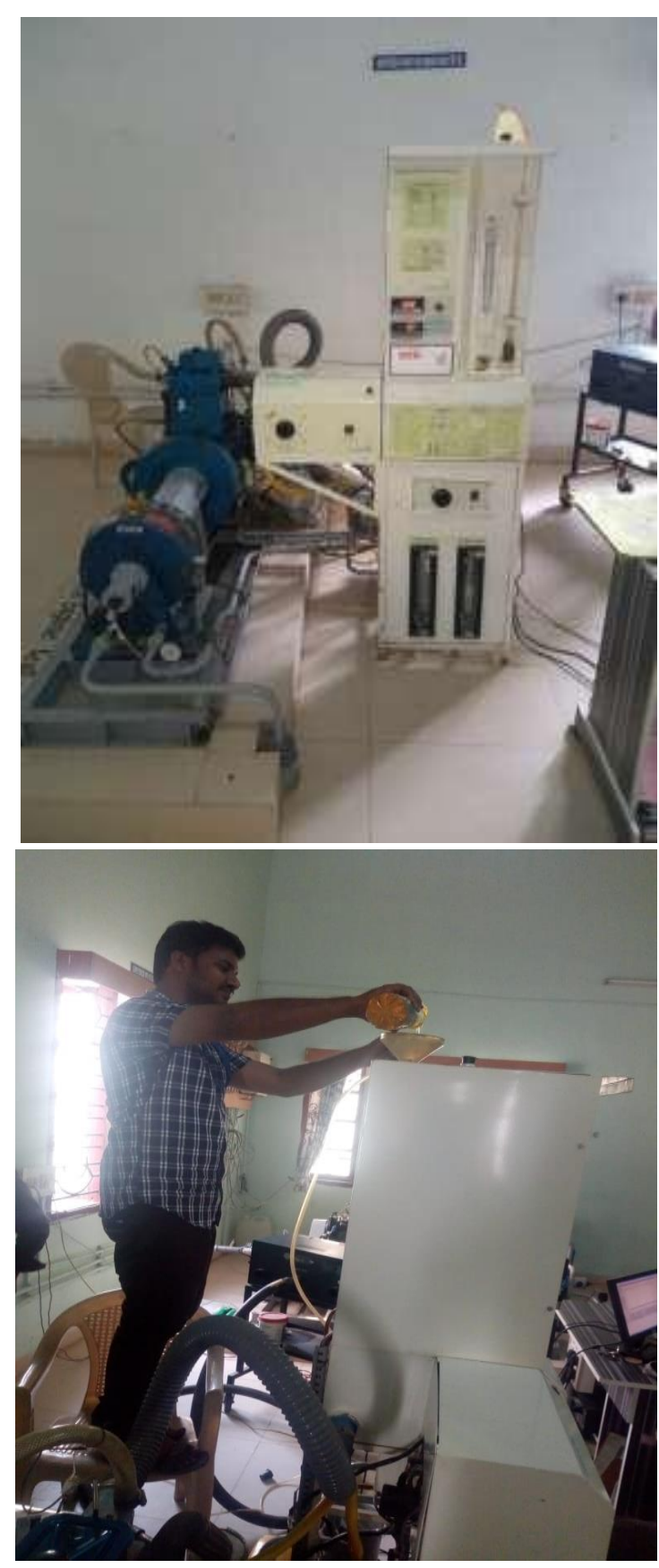

Fig.2. Complete Experimental engine setup

\begin{tabular}{|l|l|}
\hline Engine make & $\begin{array}{l}\text { VCR Engine test setup 1 } \\
\text { cylinder, 4 stroke, Diesel } \\
\text { with EGR (Computerized) }\end{array}$ \\
\hline Type & $\begin{array}{l}\text { Kirloskar, Type 1 } \\
\text { cylinder, 4stroke Diesel, } \\
\text { water cooled. }\end{array}$ \\
\hline EGR & $\begin{array}{l}\text { Water cooled, ss 304, } \\
\text { Range 0-20\% }\end{array}$ \\
\hline
\end{tabular}




\begin{tabular}{|c|c|}
\hline Displacement & $661 \mathrm{cc}$ \\
\hline Bore \& Stroke & $875 \mathrm{~mm} \& 110 \mathrm{~mm}$ \\
\hline Compression ratio & 12 to 18 \\
\hline Fuel & Diesel \&Petrol \\
\hline Rated brake Power & $3.5 \mathrm{KW}$ \\
\hline Rated Speed & 1500rpm \\
\hline Dynamometer & $\begin{array}{l}\text { Eddy current, water } \\
\text { cooled with loading unit }\end{array}$ \\
\hline Ignition system & Compression Ignition \\
\hline $\begin{array}{l}\text { Injection point } \\
\text { variation }\end{array}$ & 0-25 deg BTDC \\
\hline Connecting rod length & $234 \mathrm{~mm}$ \\
\hline Software & $\begin{array}{l}\text { "IC Engine Soft" Engine } \\
\text { performance analysis } \\
\text { software }\end{array}$ \\
\hline
\end{tabular}

Table 4: Test Engine specifications

\section{Test procedure}

Experiment has been conducted on with diesel and cottonseed oil, hexanol biodiesel with cerium oxide as an additive. The test was carried out with in two stages. In the first stage the experimental examination was done by using standard diesel. In second stage of examination the cottonseed oil and hexanol biodiesel with cerium oxide as an additive blends are used i.e blend10 blend15 and blend 20 The cooling of the engine is accomplished by circulating water through the jacket soft hecylinderhead and the engine block.

\section{RESULTS AND DISCUSSION}

The biodiesel blends was successfully tested on the engine setup and the results was drawn Performance characteristics such as Brake Thermal Efficiency and Brake Specific Fuel Consumption were measured. Performance characteristic graphs were plotted. One is for Brake Power Vs Brake Thermal Efficiency and the second is for Brake Power Vs Brake Specific Fuel Consumption and we can analyze and compare the results among different blends of fuels.

\section{A.Brake Power Vs Brake Thermal Efficiency}

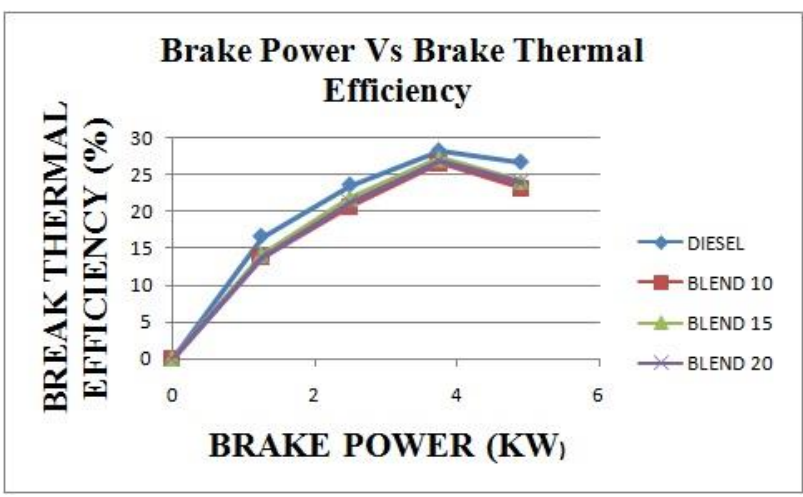

Fig 3. Brake Power Vs Brake Thermal Efficiency

In Fig 3, the graph between brake $\mathrm{v}_{s}$ thermal efficiency for various biodiesel blends .At $9 \mathrm{~kg}$ load, it was observed that the Brake Thermal Efficiencies for Diesel, Blend 10, Blend 15 and Blend 20 are 28.32\%, $26.62 \%, 27.25 \%$ and $26.93 \%$ respectively.

The graph was drawn between Brake power and Brake Thermal Efficiency for Diesel and blends of Blend 10, Blend 15 and B lend20. The Fig 3, shows that, the Brake Thermal Efficiency for Diesel is more (Maximum at $9 \mathrm{~kg}$ load i.e., BTE-28.32\%) and Blend 15 (BTE-27.25\%) is approximately near to diesel compared with other blends.

\section{B.Brake Power Vs Brake Specific Fuel Consumption}

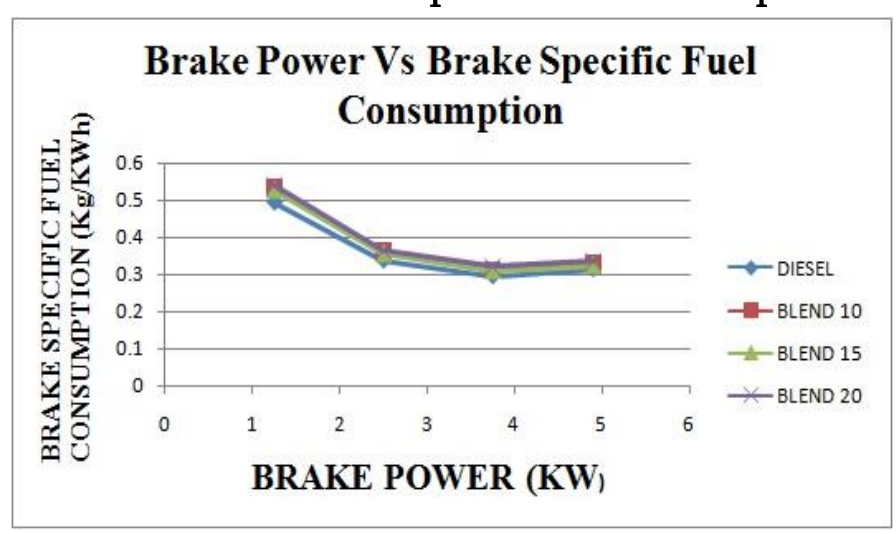

Fig 4: Brake Power Vs Brake Specific Fuel Consumption 
In fig 4,shows the graphs between brake poweVs brake specific fuel consumptionit was observed that At $9 \mathrm{~kg}$ load, Brake Specific Fuel Consumption for Diesel, Blend 10, Blend 15 and Blend 20 are 0.295, $0.313,0.309$ and $0.321 \mathrm{Kg} / \mathrm{kWh}$ respectively.

The above graph for Brake Specific Fuel Consumption (BSFC) was drawn for Diesel and for the blends of Blend 10, Blend 15 and Blend 20; Diesel shows the minimum brake specific fuel consumption $0.295 \mathrm{Kg} / \mathrm{kWh}$ at load 9kgand Blend20 shows the highest brake specific fuel consumption among all loads.

\section{EMISSIONS ANALYSIS}

The main constituents of the emissions are Carbon Monoxide (CO), Hydrocarbons (HC) and Oxides of Nitrogen (NOx). The three types of emissions were measured and graphs were plotted against Brake Power to analyze and compare the results with different blends and also with nanoparticles various concentrations.

\section{C.Brake Power Vs HC emissions}

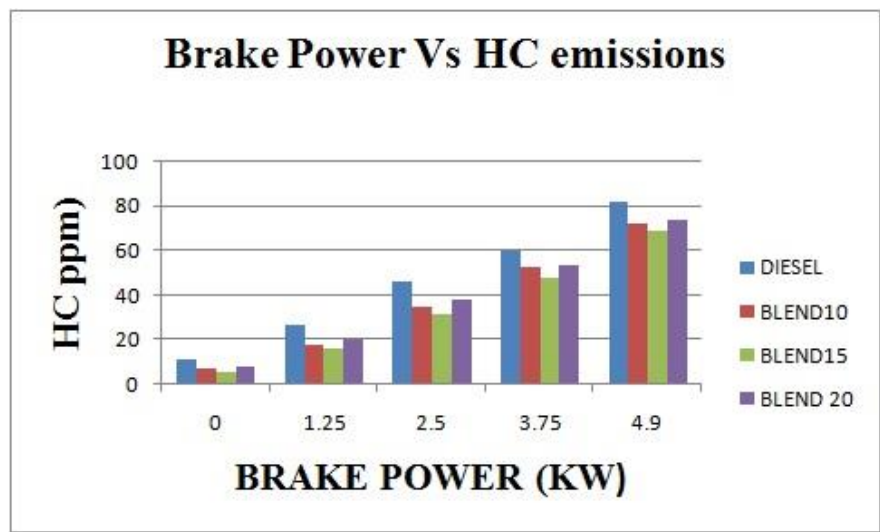

Fig 5. Brake Power Vs HC emissions

Fig 4 shows the emissions graphs of hydrocarbons for various blends. Inthis graph we absorbed that the At $9 \mathrm{~kg}$ load, Unburnt Hydrocarbon (HC) emissions for Diesel, Blend 10, Blend 15 and Blend 20 are 60, 53, 48and 54 ppm respectively.
Addition of hexanol biodiesel reduces the HC emissions compared with diesel and the above graph shows that among all, Blend 15 blend gives the lowest reduction of compared with diesel HC emissions.

\section{D.Brake Power Vs CO emissions}

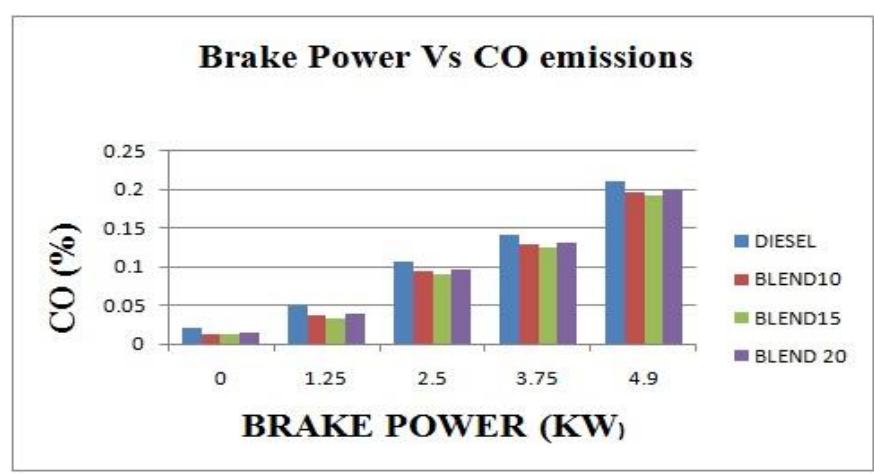

Fig 6. Brake Power Vs CO emissions

Fig 6 shows the emission graph of carbon monoxide and brake power At 9kg load, Carbon Monoxide emissions for Diesel, Blend 10, Blend 15 and Blend 20 are $0.141 \%, 0.128 \%, 0.123 \%$ and $0.131 \%$ respectively. Carbon Monoxide emissions are due to incomplete combustion of fuel. With the use of biodiesel, the amounts of $\mathrm{CO}$ emissions were decreased. From the graph Blend15 produces less $\mathrm{CO}$ emissions compared with diesel.

\section{E. Brake Power Vs NOx emissions}

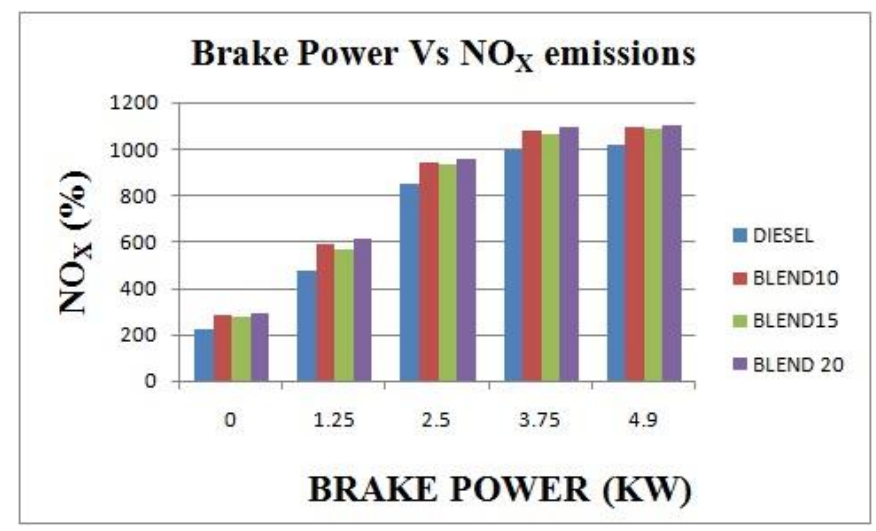

Fig 7. Brake Power Vs NOx emissions 
Fig 7, shows the graph between brake power and oxides of nitrogen. It was observed that the At $9 \mathrm{~kg}$ load, Oxides of Nitrogen (NOx) for Diesel, Blend 10, Blend 15 and Blend 20 are 994, 1078, 1066 and 1090 ppm respectively. 9640526761

The addition of biodiesel results in higher $\mathrm{NOx}$ emission compared with diesel. The graph above shows that Diesel produces less NOx compared to biodiesel blends, and Blend 15 produces the second lowestemissions .

\section{CONCLUSION}

The performance and emission results of various blends are analyzed. The results are best for Blend 15 blend compared with other blends in terms of Brake Thermal Efficiency, Brake Specific Fuel Consumption, $\mathrm{HC}, \mathrm{CO}$ and $\mathrm{NOx}$ emissions.

With the best resulted blend (Blend 15), add various concentrations of Cerium Oxide Nanoparticles of 20, 40 and $60 \mathrm{ppm}$ on weight basis and compare the results with Diesel.

\section{ANALYSIS OF BLENDS WITH $\mathrm{CeO}_{2}$ PERFORMANCE ANALYSIS}

\section{F. Brake Power Vs Brake Thermal Efficiency}

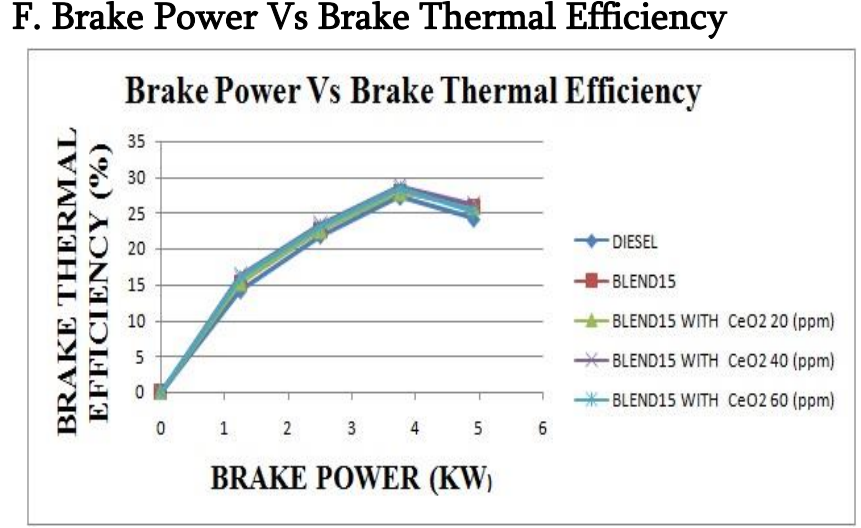

Fig 8. Brake Power Vs Brake Thermal Efficiency

The graph between brake power and brake thermal efficiency.Blend 15 is added with different concentrations of Cerium Oxide nanoparticles of 20, 40 and $60 \mathrm{ppm}$. Atload $9 \mathrm{~kg}$, Brake Thermal Efficiencies for Diesel, Blend 15, Blend $15+\mathrm{CeO}_{2} 20 \mathrm{ppm}$, Blend $15+\mathrm{CeO}_{2} 40 \mathrm{ppm}$ and $\mathrm{B} 15+\mathrm{CeO}_{2} 60 \mathrm{ppm}$ are $28.32 \%$, 27.25\%, 27.95\%, 28.73\% and $28.42 \%$ respectively.

The above graph was plotted among diesel, Blend 15 and other nano additives, which shows that Brake Thermal Efficiency for Blend15+CeO $440 \mathrm{ppm}$ gives (BTE-28.73\%) approximately equal to the pure diesel which is more than other concentrations.

\section{G.Brake Power Vs Brake Specific Fuel Consumption}

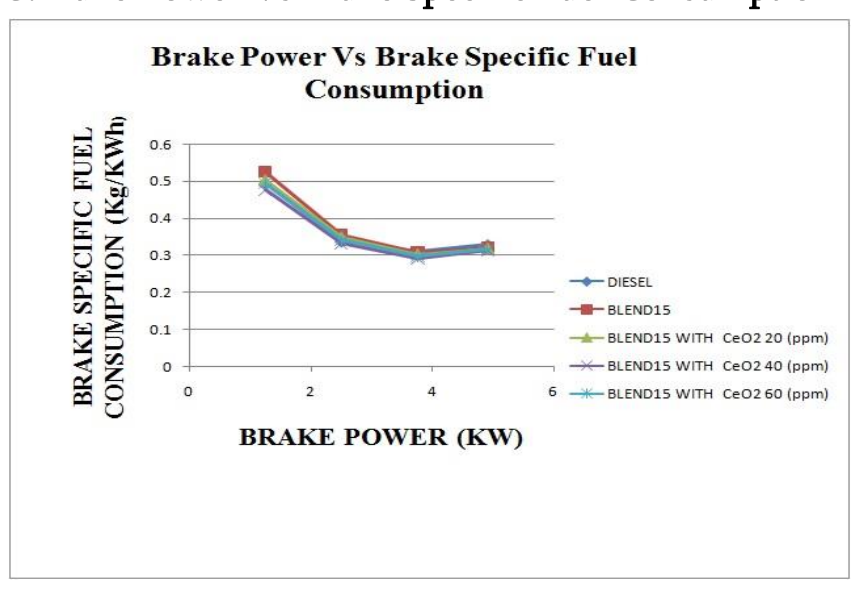

Fig 9. Brake Power Vs Brake Specific Fuel Consumption

The graph between brake power and brake specific fuel consumption At load 9kgs, Brake Specific Fuel Consumption for Diesel, B15, Blend15 $+\mathrm{CeO}_{2}, 20 \mathrm{ppm}$ Blend $15+\mathrm{CeO}_{2} 40 \mathrm{ppm}$ and $\mathrm{B} 15+\mathrm{CeO}_{2} 60 \mathrm{ppm}$ are $0.311,0.309,0.303,0.292$ and 0.297 respectively.

From the graph Cerium Oxide nanoparticles added with Blend 15 with 40 ppm of $\mathrm{CeO}_{2}$ (BSFC- 0.292 $\mathrm{Kg} / \mathrm{kWh}$ ) gives the lowest BSFC compared with 20 and $60 \mathrm{ppm}$ and also compared with diesel. 


\section{EMISSIONS ANALYSIS}

\section{H. Brake Power Vs HC emissions}

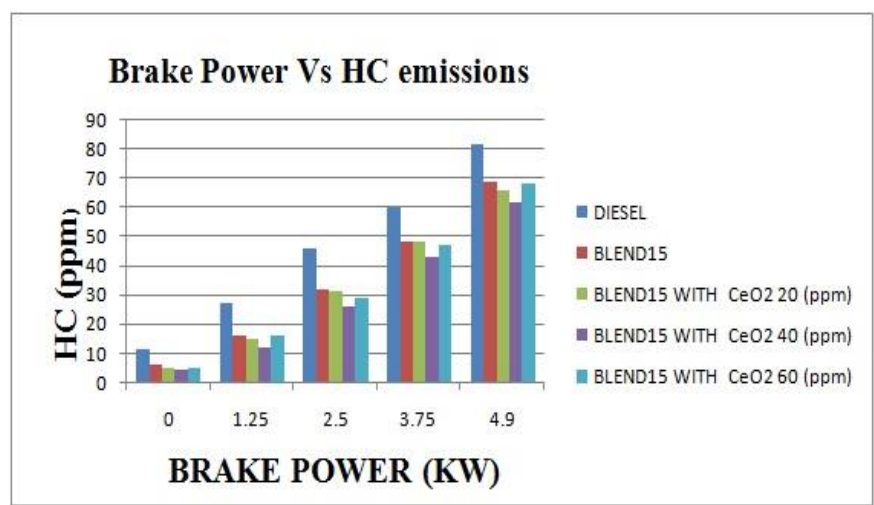

Fig 10. Brake Power Vs HC emissions

In Fig 10, the graph between Brake Power Vs HC emissions At load 9kgs, Unburnt hydrocarbons (HC) emissions for Diesel, Blend15, Blend15+CeO $20 \mathrm{ppm}$, Blend $15+\mathrm{CeO}_{2} 40 \mathrm{ppm}$ and Blend $15+\mathrm{CeO}_{2} 60 \mathrm{ppm}$ are $60,48,48,43$ and 47 respectively.

Cerium Oxide nanoparticle $\mathrm{CeO}_{2}$ acts as an antioxidant and improve the combustion efficiency that reduces the $\mathrm{HC}$ emissions. The graph above shows that, out of $20 \mathrm{ppm}$ and $60 \mathrm{ppm}$ of $\mathrm{CeO}_{2}, 60 \mathrm{ppm}$ gives the lowest $\mathrm{HC}$ emissions which is lower than Diesel emissions.

\section{I.Brake Power Vs CO emissions}

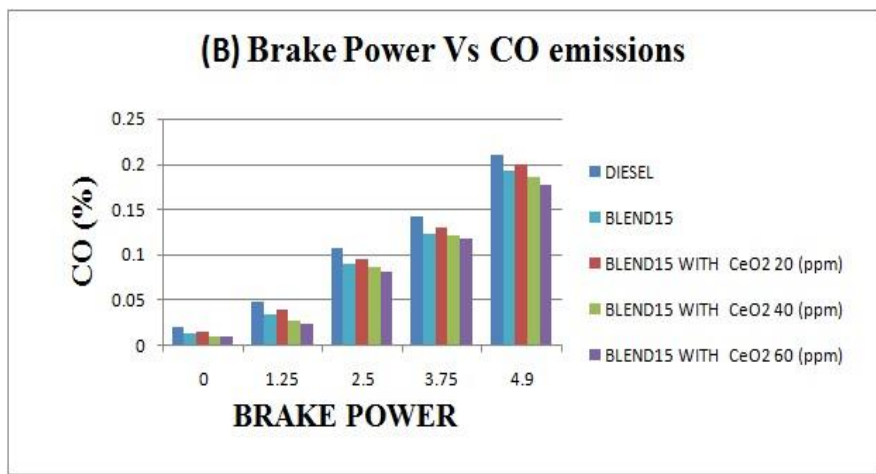

Fig 11: Brake Power Vs CO emissions

Fig 11 shows the graph between brake power and co emissions At load 9kg, Carbon Monoxide emissions for Diesel, Blend 15, Blend15+CeO $220 \mathrm{ppm}$,
$\mathrm{B} 15+\mathrm{CeO}_{2} 40 \mathrm{ppm}$ and $\mathrm{B} 15+\mathrm{CeO}_{2} 60 \mathrm{ppm}$ are $0.141 \%$, $0.123 \%, 0.132 \%, 0.121 \%$ and $0.117 \%$ respectively.

With the addition of nanoparticles, the amounts of $\mathrm{CO}$ emissions are reduced due complete combustion. Thegraph shows thatBlend $15+\mathrm{CeO}_{2} 60$ ppmgives the lowest CO emissionsDiesel emissionsout of other concentrations.

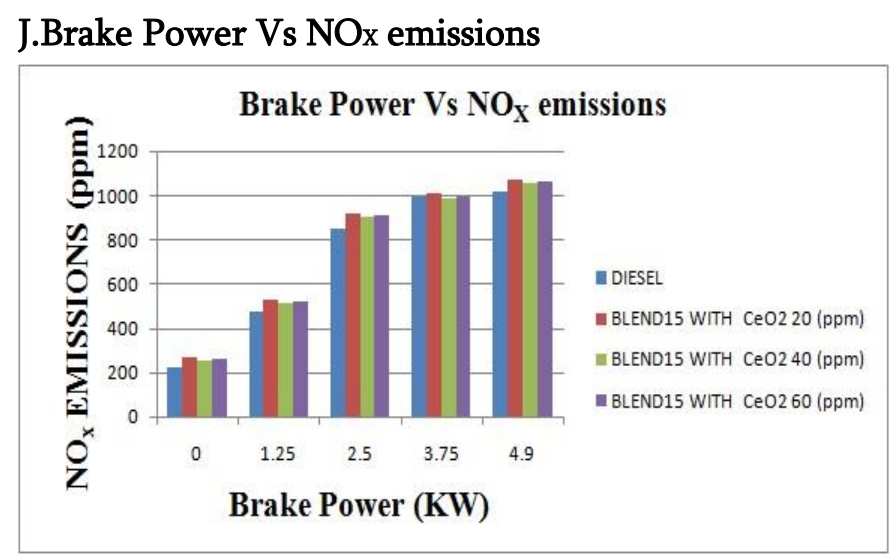

Fig 12. Brake Power Vs NOx emissions

Fig 12 shows the emission graph between brake powerand oxides of nitrogen At 9kgs load, Oxides of Nitrogen (NOx) for Diesel, Blend15, Blend 15+ $\mathrm{CeO}_{2} 20 \mathrm{ppm}, \mathrm{B} 15+\mathrm{CeO}_{2} 40 \mathrm{ppm}$ and $\mathrm{B} 15+\mathrm{CeO}_{2} 60 \mathrm{ppm}$ are 994, 1066, 1012, 988 and 994 respectively.

From the graph we can observe that by adding the Cerium Oxide nanoparticles the amount of $\mathrm{NOx}$ emissions are decreased at $60 \mathrm{ppm}$ of $\mathrm{CeO}_{2}$ compared with 30 and $90 \mathrm{ppm}$ but it is $0.81 \%$ less than Diesel emissions.

\section{IV.CONCLUSION}

The performance and emissions behaviour of various biodiesel blends were performed on single cylinder diesel engine The addition of cotton seed oil and hexanol on biodiesel as a blend with concentrations of 10, 15 and 20ppm with diesel and conducted the experiments and analyze the results of performance and emission characteristics. Blend 15 gives the better performance and emission characteristics but 
NOx emissions are more. To avail the benefit of Cerium Oxide nanoparticle's anti-oxidant and catalytic properties to improve complete combustion and reduce NOx, 20, 40 and 60 ppm concentrations of $\mathrm{CeO}_{2}$ is added. Out of all these concentrations $40 \mathrm{ppm}$ with Blend 15 blend gives the better performance and emission characteristics. And the following results was obtained.Maximum Brake Thermal Efficiency for Diesel is 28.32\%.Maximum Brake Thermal Efficiency for Blend15 is 27.25\%.Maximum Brake Thermal Efficiency for $\mathrm{B} 15+\mathrm{CeO}_{2} 40 \mathrm{ppm}$ is $28.73 \%$.So efficiency of Blend $15+\mathrm{CeO}_{2} 60$ is approximately equal to diesel efficiency.Compared with Diesel emissions,For CO emissions of B15+ $\mathrm{CeO}_{2} 40$,ppm it is reduced by $18.42 \%$. For $\mathrm{HC}$ emissions of $\mathrm{B} 15+\mathrm{CeO}_{2} 40$,ppm it is reduced by $31 \%$. For NOx emissions of $\mathrm{B} 15+\mathrm{CeO}_{2} 40$,ppm it is reduced by $0.82 \%$.One can reduce the significant amount of $\mathrm{CO}$ and $\mathrm{HC}$ emissions considerably and especially NOx emissions are also reduced with the help of $\mathrm{CeO}_{2}$ nano additive.

\section{REFERENCES}

[1]. Murat Karabektas, The effects of preheated cottonseed oil methyl ester on the performance and exhaust emissions of a diesel engine. Applied Thermal Engineering, 28, 2008, 2136-2143.

[2]. Nurun Nabi Md, Biodiesel from cotton seed oil and its effect on engine performance and exhaust emissions. Applied Thermal Engineering, 29, 2009, 2265-2270.

[3]. Obed M, Ali, Analysis of blended fuel properties and cycle-to-cycle variation in a diesel engine with a diethyl ether additive. Energy Conversion and Management, 108, 2016, 511-519.

[4]. Patil KR, Experimental investigation of CI engine combustion, performance and emissions in DEEkerosene-diesel
[5]. Ecklund,E.E.,etal.,State-of-the-Art Report on the Use of Alcohols in Diesel Engines SAE paper 840118.1984

[6]. Zaidi, K., Andrews, G. E., Greenhaugh, J. H., Diesel Fumigation Partial Premixing

[7]. ForReducing Ignition Delay and Amplitude of Pressure Fluctuations, SAE paper 980535, 1998

[8]. Sundar Raj, C., et al., Performance Achievements and Emission Control on DI Diesel Fumigated with Methanol Using Microprocessor Controlled Fumigator, (TIDEE) TERI Information Digest on Energy and Environment, 8 (2009), 1, pp. 35-39

[9]. Sundar Raj, C., Arul S., Sendilvelan, S., Some Comparative Performance and Emission Studies on DI Diesel Engine Fumigated with Methanol and Methyl Ethyl Ketone Using Microprocessor Controlled Fumigator, The Open Fuels \& Energy Science Journal, 1 (2008), pp. 74-78

[10]. Honne Gowda G. A. Usmani —Characterization Of Bio-Diesel Obtained From Pure SoyabeanOil And Its Various Blends With Petro-Diesel, International Journal Of Innovative Research In Downloaded by[Gotheburng University Library] at Nov 2017

[11]. Joshua Marcus Paul, 2gowdham .D "Emission Characteristics Of Cerium Oxide NanoparticleBlended Emulsified Biodiesel" 1,2Mechanical Engineering Department, Panimalar EngineeringCollege , April, 2016 Pp 36-39

\section{Cite this article as :}

M. Anilkumar, Dr. K. Prahladarao, "Performance and Emission Characteristics of Cotton Seed and Hexanol Oil Biodiesel with $\mathrm{CeO} 2$ Additives on Single Cylinder Diesel Engine", International Journal of Scientific Research in Science and Technology (IJSRST), Online ISSN : 2395-602X, Print ISSN : 2395-6011, Volume 6 Issue 5, pp. 275-282, September-October 2019. Available at doi : https://doi.org/10.32628/IJSRST19648 Journal URL : http://ijsrst.com/IJSRST19648 